\title{
SUPERFICIAL GANGRENE OF THE SKIN IN CHICKENPOX
}

\author{
BY
}

\author{
R. S. ILLINGWORTH and R. B. ZACHARY \\ From the Children's Hospital Unit, the United Sheffield Hospitals
}

(RECEIVED FOR PUBUCATION OCTOBER 27, 1954)

Gangrene of the skin is a very rare complication of chickenpox. Barenberg and Lewis (1927) saw one example in over 2,000 children and Wishik and Bullowa (1935) saw four examples in 2,534 children with chickenpox. The condition was probably first described by Stokes (1807), but was first discussed in some detail by Jonathan Hutchinson in 1882 . The latter's paper is notable for the beautiful reproduction in colour of a painting of a child with multiple areas of gangrene. Hutchinson termed the condition 'varicella gangrenosa'. Crocker (1903) described it under the heading 'dermatitis gangraenosa infantum (synonyms varicella gangraenosa, pemphigus gangraenosa, rupia escharotica, echthyma térébrant, echthyma gangrenosum)'.

In most of the cases described the gangrene occurred around one or more of the chickenpox lesions (Hutchinson, 1882; Crocker, 1903; Barenberg and Lewis, 1927; Rundle, 1929; Apert and Goldberg, 1930; Lavergne, Helluy and Bolikowska, 1938; Joe, 1947). In the majority of cases described the lesions were multiple, but in both Storrie's cases (1914) there was a single gangrenous area. In almost all the cases described the gangrene developed between the fourth and seventh day of the eruption.

Views as to the aetiology of the condition are varied. Hutchinson (1882) held that it was due to an individual susceptibility to varicella, a view with which Barenberg and Lewis (1927) and Stoesser and Lockwood (1938) agreed. Schamberg and Kolmer (1928) regarded the condition as non-specific, stating that similar manifestations may occur in vaccinia, variola, scarlatina and various dermatoses.

Several workers, for example, Schamberg and Kolmer (1928), Rundle (1929) and Joe (1947), thought that it occurred largely in weakly and malnourished children, many of them with tuberculosis, though other workers were impressed by the good general condition of affected children, for example, Dykes (1927) and Barenberg and Lewis (1927).

Several workers ascribed the complication to secondary infection. Krjukoff (1899), Goodall (1928) and Joe (1928) described cases from which the Klebs-Loeffler bacillus was isolated. Banks and McCartney (1937) isolated the haemolytic streptococcus of Griffith Type 23 from lesions in their case, and ascribed the infection to an associated tonsillitis from which the same organism was recovered. Storrie (1914) obtained Staphylococcus pyogenes from his two cases. Nichols (1934) isolated the same organism from a case with superficial gangrene of the abdominal wall following infection of a vesicle. Gillespie and Porter (1952) described the occurrence of cellulitis or gangrene in three members of one family - the mother and two children: the lesions had to be incised and drained. In three of the cases described by Wishik and Bullowa (1935) the gangrene was preceded by cellulitis and high fever.

In some cases there was an associated thrombocytopenic purpura (Stoesser and Lockwood, 1938); Batch and Sepkowitz, 1952). In most of the studies in the literature there is no record of a platelet count. Watson (1934) commented on the ecchymosis surrounding the gangrenous area in his case.

Almost all writers emphasized the grave toxaemia experienced by their patients (Hutchinson, 1882; Storrie, 1914; Barenberg and Lewis, 1927; Dykes, 1927; Gordon, 1927; Goodall, 1928; Nichols, 1934; Watson, 1934; Banks and McCartney, 1937). Most of the patients described by the above writers died. Storrie collected 43 cases from the literature, 29 of which died. On the other hand one of the patients described by Wishik and Bullowa (1935) was never ill, though he developed gangrene of all the fingers of one hand, the dorsum of one foot, and part of both legs. New areas of gangrene developed 16 days after the first. Schamberg and Kolmer (1928) described the occurrence of mild cases. Dykes (1927), Watson (1934), Wishik and Bullowa (1935) and others noted the mildness of the initial chickenpox. The patient described by Dykes, for instance, had no more than 20 vesicles in all. 
Several workers commented on the rapidity with which the gangrene spread. In the case described by Watson (1934), for instance, a small discoloured area developed on the fourth day of the chickenpox eruption, gangrene was obvious eight hours later, and 20 hours later there was a gangrenous area 6 in. wide spreading from the axilla to the iliac crest. The patient recovered. The patient described by Banks and McCartney (1937) died within 48 hours of the appearance of gangrene.

Below is a description of a child observed by us in the Children's Hospital at Sheffield.

\section{Case Report}

The patient was a well nourished 3-year-old girl who developed typical mild chickenpox a week after her brother started with it. In the evening of the seventh day of the eruption she went to bed well, but woke on the following morning with a swollen and tender purple patch, about $1 \frac{1}{2}$ in. in diameter, with red edges, on the front of the left side of the chest. She was not at all poorly. An hour later the patch was said to be almost twice its initial size. There had been no injury and no ointment or other medication had been applied to the area. On the following day she was brought (walking) into the Out-patient Department.

On examination she was a well looking girl, weighing $30 \mathrm{lb}$., and with a normal temperature. Her blood pressure was $85 / 60 \mathrm{~mm}$. Hg. There was a typical rash of mild chickenpox. On the front of the left side of the chest there was an irregular ovoid patch of gangrene, measuring $8 \times 4 \mathrm{~cm}$., with a clearly demarcated red periphery about $1 \mathrm{~cm}$. in width (Figs. 1 and 2). The whole area was somewhat indurated and raised above the level of the surrounding tissues, but there was no suggestion of cellulitis. The temperature of the gangrenous patch

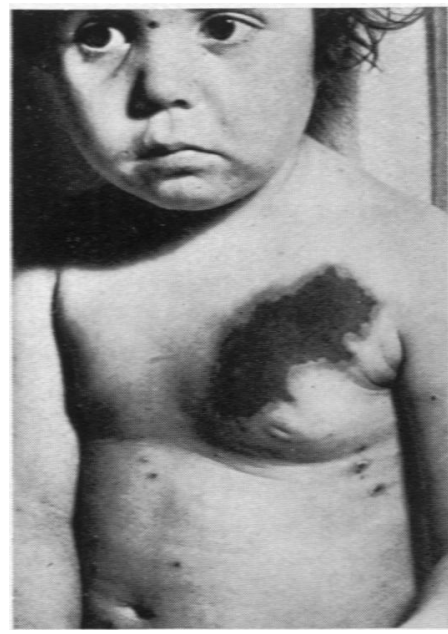

FiG. 1.-On the day after admission.

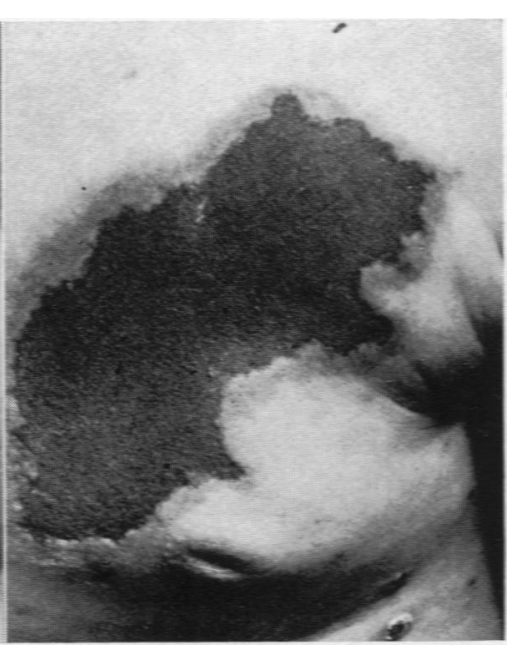

FiG. 2. On the day after admission (close-up view). was less than that of the tissues around. On pressing the stethoscope bell into the surrounding tissues there was a fine crepitus, similar to that obtained in the presence of subcutaneous emphysema. The skin surface was not bruised or excoriated. There was only slight tenderness to the touch. There was no associated lymphadenopathy, and there were no other abnormal physical signs elsewhere in the body. There was no evidence of arteriosclerosis. Instructions were given that the affected area should be kept dry and absolutely clean, but no specific therapy was prescribed.

Special investigations were negative. The blood count was as follows: Haemoglobin, $11 \cdot 7 \mathrm{~g}$. ${ }^{\circ}$; red cells $3,300,000$ per c.mm.; white cells 13,500 per c.mm. (neutrophils $59 \%$, lymphocytes $30 \%$, monocytes $7 \%$, eosinophils $4 \%$ ); platelets 433,000 per c.mm.

The bleeding time was $3 \frac{1}{2}$ minutes. The Mantoux test $(1$ in 1,000) was negative. The urine was normal chemically and microscopically. A radiograph of soft tissues underlying the gangrenous area did not help. The gangrenous area being quite dry and clean, no bacteriological examination was possible.

She made an uneventful recovery. She remained well and afebrile, with no toxaemia. At no time was there any serous or other discharge from the area. On the day after admission the swelling was less marked, and there was no crepitus on pressure. There was some surrounding discoloration, as if there were an underlying haematoma. but an aspirating needle was passed through adjacent normal skin and under the lesion, without revealing any sign of blood. On the ninth day after admission desquamation began in the peripheral red area, revealing an underlying healthy pink skin. She was discharged home after 15 days in hospital. The gangrenous area gradually shrank, so that by the 22nd day it measured $7.7 \times 2 \mathrm{~cm}$. Six weeks after the onset desquamation of the gangrenous area began, leaving a clean healed scar underneath. Eight months after the onset the affected area had healed completely (Fig. 3), leaving a scar

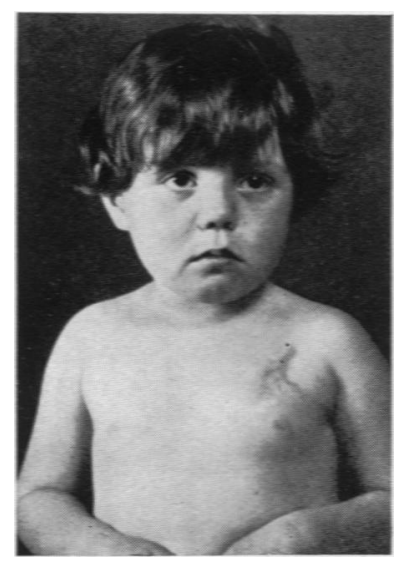

Fig. 3.-Eight months after the onset. 
measuring $6 \times 2 \mathrm{~cm}$., some of it soft, some of it a little indurated. It was felt that for the present no plastic surgery on the scar was advisable because it was hoped that it would contract down still more. The girl was asked to return in a year for review.

\section{Comment}

The outstanding feature of our case was the absence of fever or toxaemia in spite of a fairly large patch of gangrene. There was no sign of secondary infection and the patch of gangrene bore no obvious relationship to any chickenpox lesion: it did not surround or abut on a vesicle or scab. The platelet count was normal. The above facts lend some support to the original view expressed by Hutchinson (1882) that gangrene in these cases may represent an individual susceptibility to varicella. Other cases are clearly due to secondary infection.

\section{Summary}

A case of superficial gangrene of the skin in a mild case of chickenpox is described. There was no evidence of secondary infection. The child at no stage showed toxaemia or an elevation of temperature, remaining well throughout. The treatment was entirely conservative.
We wish to thank Dr. Doris Fletcher, dermatologist, for seeing this case. Dr. Judith Hay kept accurate day-to-day records of the size and appearance of the lesion. The clinical photographs are by the Department of Medical Photography in the United Sheffield Hospitals. We also wish to thank the family doctor, Dr. J. C. Cooper of Sheffield, for referring the girl to us.

\section{REFERENCES}

Apert, E. and Goldberg (1930). Bull. Soc. Pédiat., Paris, 28, 106. Banks, H. S. and McCartney, J. E. (1937). Lancet, 2, 311 Barenberg. L. H. and Lewis, J. M. (1927). Arch. Pediat., 44, 653. Batch, J. W. and Sepkowitz, S. (1952). U.S. armed Forces med. J. 3, 759.

Crocker, H. Radcliffe (1903). Diseases of the Skin, 3rd ed., vol. 1, p. 485 . London.

Dykes, S. N. (1927). Brit. med. J., 1, 511

Gillespie, J. B. and Porter, G. L. (1952). Arch. Pediat., 69, 51

Goodall, E W. (1928). A Text-book of Infectious Diseases. London.

Gordon, E. (1927). Arch. Pediat., 44, 337.

Hutchins. J (1882) Med-Chir. Trans. 65, 1

Hutchinson, J. (1882). Med.-Chir. Trans.,

Joe, A. (1928). Brit. J. Child. Dis., 25, 111. London.

Krjukoff, A. (1899). Arch. Kinderheilk., 27, 420 . Quoted by Banks and McCartiney (1937).

Lavergne, V. de, Helluy, J. R. and Bolikowska, H. (1938). Rer. méd. Nancy, 6, 411. Quoted by Van Rooyen, C. E. and Rhodes, A. J. (1948).

Nichols, T. R. (1934). Canad. med. Ass. J., 30, 297.

Rundle, C. (1929). Ker's Infectious Diseases. London.

Schamberg, J. F. and Kolmer, J. A. (1928). Acute Infectious Diseases, 2nd ed. p. 319. Philadelphia.

Stoesser, A. V. and Lockwood, W. W. (1938). J. Pediat., 12, 641

Stokes, W. (1807). Dublin med. phys. Essays, 1, 146. Quoted by Hutchinson, J. (1882)

Storrie, H. C. (1914). Brit.j. Child. Dis., 11, 62

Watson, T. M. (1934). J. Amer. med. Ass., 102, 2179

Watson, T. M. (1934). J. Amer. med. Ass., 102, 2179.
Wishik, S. M. and Bullowa, J. G. M. (1935). Amer. J. Dis. Child., 49, 927. 